\title{
Regulatory Impact Assessment in Pandemic Times: a practical exercise on the COVID-19 context $^{8}$
}

\author{
Daniel Marques Mota ${ }^{1}$ \\ Flavio Saab ${ }^{1,2}$ \\ Raisa Zandonade Vazzoler ${ }^{1}$ \\ Karina Schunig ${ }^{1}$ \\ Edson Antônio Donagema ${ }^{1}$ \\ Gabrielle Cunha Barbosa Cavalcanti e Cysne Troncoso ${ }^{1}$ \\ ${ }^{1}$ Anvisa (Brazilian Health Regulatory Agency), Brasília - DF, Brazil \\ ${ }^{2}$ UnB, Brasília - DF, Brazil
}

This study aims to demonstrate the potential use of problem identification and analysis, one of the Regulatory Impact Assessment (RIA) stages, as an alternative to drive critical, rational, and logic thinking while formulating regulatory policies and actions to face COVID-19. The theoretical foundation included an outlook on regulation, RIA and problem identification and analysis. The authors performed a descriptive study with a qualitative approach to report on the results of the didactic-pedagogical workshop, related to problem identification and analysis on a COVID-19 situation. Seven federal workers and one trainee from the regulatory quality improvement area in Anvisa participated in the workshop. "SARS-COV-2 coronavirus dissemination, as a little- known, untreated and highly contagious virus" was the main problem identified. Ten problem- related consequences were pinpointed, including the worsening of mental health. As an illustration, the study highlighted only five of the 20 causes listed by the workshop participants. One of the investigated problem causes was the low population adherence to prevention and control measures. According to the workshop participants, 30 affected stakeholders were identified in the workshop, such as the high-risk population (elderly and people with comorbidities). Thus, this study aims to contribute to the COVID-19 coping in Brazil, as well as to other future public health emergencies.

Keywords: public administration, COVID-19, regulatory impact analysis

${ }^{8}$ DOI: https://doi.org/10.21874/rsp.v71i0.4824

ISSN: 0034-9240 | E-ISSN: 2357-8017

(). (1) (9)

Submitted: June 09, 2020. Published: June 25, 2020.

REVISTA Do SERVIÇO PúBlıco ｜ Brasília 71 (special): $165-188$ set. 2020 


\section{A Análise de Impacto Regulatório em Momento de Pandemia: um exercício prático no contexto da COVID-19}

Este estudo objetivou demonstrar o potencial uso da análise e definição de problemas, uma das fases da Análise de Impacto Regulatório (AIR), como uma alternativa em direcionar um pensamento crítico, racional e lógico para a formulação de políticas regulatórias e ações para o enfrentamento da COVID-19. A fundamentação teórica envolveu um panorama sobre regulação, AIR e análise e definição do problema. Recorreu-se a um estudo descritivo com abordagem qualitativa para relatar os resultados da oficina virtual, de caráter didáticopedagógico, sobre análise e definição do problema principal no contexto da COVID-19. Participaram da oficina sete servidores e um estagiário que atuam na unidade de melhoria da qualidade regulatória na Anvisa. O problema principal definido foi "Disseminação do coronavírus SARS-COV-2, pouco conhecido, sem tratamento e com alta taxa de contágio". Foram identificadas 10 consequências relacionadas ao problema, sendo o agravamento de problemas ligados à saúde mental uma delas. A título ilustrativo, o estudo destacou cinco das 20 causas elencadas pelos participantes. A baixa adesão da população às medidas de prevenção e controle foi considerada uma das causas do problema. A população de grupos de risco, como idosos e pessoas com comorbidades, foi um dos 30 agentes afetados pelo problema identificados na oficina. Este estudo é uma contribuição ao enfretamento da COVID-19, bem como a outras futuras emergências em saúde pública.

Palavras-chave: administração pública, COVID-19, análise de impacto regulatório

\section{El Análisis del Impacto Regulatorio en el momento de la pandemia: un ejercicio práctico en el contexto del COVID-19}

Este estudio tuvo como objetivo demostrar el uso potencial del análisis y la definición de problemas, una de las fases del Análisis de Impacto Regulatorio (AIR), como una alternativa para dirigir el pensamiento crítico, racional y lógico para la formulación de políticas y acciones regulatorias para enfrentar el COVID-19. La base teórica implicaba una visión general de la regulación, el AIR y el análisis y la definición del problema. Se utilizó un estudio descriptivo con un enfoque cualitativo para informar los resultados del taller virtual sobre análisis y definición del problema principal en el contexto de COVID-19. Siete empleados y un interno que trabajan en la unidad de mejora de la calidad reguladora en Anvisa participaron en el taller. El principal problema definido fue "Diseminación del coronavirus SARS-COV-2, poco conocido, no tratado y con una alta tasa de contagio". Se identificaron 10 consecuencias relacionadas con el problema, y el empeoramiento de los problemas de salud mental fue uno de ellos. Como ilustración, el estudio destacó cinco de las 20 causas enumeradas por los participantes. La baja adherencia de la población a las medidas de prevención y control se consideró una de las causas del problema. La población de grupos de riesgo, como los ancianos y las personas con comorbilidades, fue uno de los 30 agentes afectados por el problema identificado en el taller. Este estudio es una contribución para hacer frente a COVID-19, así como a otras futuras emergencias de salud pública.

Palabras clave: administración pública, COVID-19, análisis de impacto regulatorio 


\section{Introduction}

Infectious diseases, such as influenza, malaria and tuberculosis, pose significant threats to society. While some of these are endemic to specific geographic areas, others can spread rapidly, becoming epidemics when populations from various countries are affected (DELIVORIAS et al. 2020).

COVID-19 disease, which is caused by the new SARS-COV-2 (Severe Acute Respiratory Syndrome Coronavirus 2) coronavirus and originated in Wuhan city (China) in December 2019, was declared by the World Health Organization (WHO) as a pandemic on March 11, 2020 (OPAS, 2020).

In Brazil, after the confirmation of the first case on February 26, 2020, COVID-19 epidemiological and health surveillance actions, along with prevention and control measures and other initiatives, were intensified to minimize the damage to the population, the health care system (RODRIGUEZ-MORALES et al. 2020) and the economy. On March 20, 2020, the Ministry of Health acknowledged the occurrence of coronavirus (COVID-19) community transmission throughout the country (BRAZIL, 2020).

The loss of human lives is the first and most crucial aspect of an epidemic/pandemic. In Brazil, as of June 4, 2020, 584,016 confirmed COVID-19 cases and 32,548 deaths have been recorded (JOHNS HOPKINS, 2020). Other consequences resulting from COVID-19 prevention and control measures, such as increased psychological, behavioral, and domestic violence problems, have been reported in the literature (MOTA et al. 2020).

The SARS-COV-2 dissemination also has important repercussions on a country's economy. Evidence reports that the Brazilian economy will shrink by $5.2 \%$ due to the COVID-19 epidemic. The main economic impacts will come from the fall in raw materials commodities value and the shutdown of sectors such as tourism (ECLAC, 2020). Moreover, vulnerable populations, particularly the poor, are likely to disproportionately suffer from the epidemic, as they may have limited access to health care and less income to protect themselves from a financial catastrophe (DELIVORIAS et al. 2020).

These considerations, as well as experience with other past epidemics, demonstrate the attention the COVID-19 problem deserves during its evolvement, leading to the need for governments, health authorities, and professionals to adjust their actions for the preparation, containment and disease consequent mitigation (COVID-19, 2020; LIPSITCH et al. 2020). The 
various levels of management and actions needed for epidemic coping can form a complex environment for decision-making in the public sector (KRUMKAMP et al. 2009).

In these conditions, managers, health professionals and specialists who formulate, communicate and guide the population on disease control and mitigation strategies have gained notoriety (COWPER, 2020). In Brazil, the lack of research in public administration creates difficulties for the use of analytical tools for policies and actions formulation to confront COVID-19 (MOTA et al. 2020).

The Regulatory Impact Assessment (RIA), a methodology used in the formulation of policies to address public problems (JACOBS 2004), can be a viable and effective alternative to guide policies and actions in times of epidemic/pandemic. RIA can provide a logical rationale in an environment where the people involved are under pressure, thus ensuring public policies and government actions are more planned and integrated, allowing the development of effective solutions to face the problem.

RIA can be used to indicate regulatory interventions at various public administration levels, through problem analysis and definition, options identification and impacts of each intervention option on society (DASKAL et al. 2019; RADAELLI, 2010). In the case of COVID-19 coping, special attention should be paid to the problem analysis and definition, which is imperative for the establishment of rapid, qualified, effective and integrated public policies and actions.

This study aims to demonstrate, through a practical exercise of didactic-pedagogical nature, the potential use of problem analysis and definition, one of the RIA phases, as an alternative in driving critical, rational and logical thinking to the formulation of regulatory policies and actions to cope with COVID-19. At this moment, no COVID-19 specific study or practical exercise of problem analysis and definition was identified that could help in the efforts to tackle the disease.

The theoretical framework related to RIA and one of its phases, the problem analysis and definition, will be presented in the following section. Next, the research methods, results and discussion along with the final considerations of the study will be presented.

\section{Theoretical framework}

\section{Regulation and Regulatory Impact Assessment}

Regulation is composed of several instruments, including laws, decrees and rules, through which governments make requirements to companies and citizens (KIRKPATRICK et al. 2004). The regulation objective is related to the promotion of public health, safety, social welfare and the 
establishment of legal certainty in the commercialization of goods and services (BALLANTINE et al. 2006).

However, regulation can have a high impact on society (DASKAL et al. 2019) and needs to be adequately developed so that its objectives are achieved and unintended consequences are not produced (CASTRO, 2014; HASSAN, 2015).

Thus, to improve their regulatory system quality, many governments have developed new processes, structures and tools to elaborate new regulations (BALLANTINE et al. 2006). Known as "better regulation", this movement implies better transparency, social participation and the use of evidence in the process of regulatory formulation (HUGÉ et al. 2011).

According to Radaelli (2004), the main tools used by governments to promote regulatory improvements are: i) RIA; ii) public consultation; iii) simplification; iv) access to regulation; and v) ex-post evaluation of the regulation. For the author, RIA is the most important tool to support regulation improvements.

RIA can be utilized in the formulation of regulatory and non-regulatory policies and is characterized as a systematic process for ex-ante evaluation of a government action's significant impacts (FRITSCH et al. 2013; KIRKPATRICK et al., 2004). It is an evidence-based analysis process that identifies the problem, defines the intended regulatory policy objectives and evaluates whether the public intervention is really necessary. Then, RIA promotes the identification, analysis and comparison of the impacts of possible intervention alternatives, in order to determine which of them is the best choice (FRITSCH et al. 2013; JACOBS, 2004).

Adopted initially in the United States in the early 1970s, RIA is already in use in developed countries and its methodology is advancing in emergent nations (CARVALHO et al. 2019; FRANCESCO, 2012).

In Brazil, RIA has been gradually implemented since 2007, with important differences in application maturity among federal regulatory agencies (AQUILA et al. 2019), especially the Brazilian Health Regulatory Agency (ANVISA), which is in an advanced state of RIA study and application in Brazil (IBRAC, 2019).

\section{Regulatory Impact Assessment in Anvisa}

In Anvisa, the RIA guidelines and procedures are described, in general terms, in Ordinance No. 1,741 of December 12, 2018, and in the Service Order No. 56 of December 18, 2018 (ANVISA, 2018a; ANVISA, 2018b). The Ordinance mentions that the process of building RIA includes three phases: I - problem analysis and definition, which aims to promote understanding about the nature, magnitude, causes and consequences of the problem and the intended objectives; II - 
regulatory options identification, which intends to map possible solutions and, whenever possible, non-normative options; and III - regulatory options comparison, which aims to identify the regulatory options' impacts and compare them, in order to demonstrate the most appropriate solution to achieve the desired objectives (ANVISA, 2018a).

In the process of developing the RIA phases, Anvisa considers virtual or face-to-face workshops incorporating Design Thinking concepts and tools to organize and stimulate innovation in the RIA collective construction process (ANVISA, 2020). Design Thinking is an approach to solving complex problems which is widely applied by various disciplines, recently emerging in the health care field (McLAUGHLIN et al. 2019).

With Design Thinking adoption in the RIA process, the formulation of regulatory policies began to rely on new dynamics, methods and tools. The focus on the human being emphasizes the importance of considering people's lives and problems, in order to seek solutions and policies that are more appropriate to human needs. Furthermore, people participating who have different perspectives and empathies throughout the process promotes the construction of solutions and policies with fewer biases and better conditions to solve real problems (CAVALCANTE et al. 2019).

During the conduction of the RIA stages, Anvisa pays special attention to the problem diagnosis stage, intending to allow the decision-maker to be able to adopt effective solutions for real needs (ANVISA, 2019).

\section{Problem analysis and definition}

The problem analysis and definition can be considered as the first and most important RIA phase. This is where efforts are made to understand the "main problem" that governments intend to face (DUDLEY et al. 2017). The problem causes and consequences are also identified, as well as evidence of its existence. It is from a clear definition of the problem, with its causes and consequences, that identifying solutions for an unwanted situation become possible (BRAZIL, 2018).

In the regulation context, the main problem may relate to a market failure or the inefficiency of government programs in achieving public objectives (MENEGUIN et al. 2020). In the first case, market conditions, which cause the regulation to be less efficient and detrimental to social wellbeing, are identified. In the second case, public objectives not achieved but desirable to society are identified (DUDLEY et al. 2017).

Regulatory problems can be multifaceted, have many causes, and affect several society stakeholders with different intensities. It is possible to perform a weighting and prioritization of the 
identified causes, both to define action objectives and to evaluate alternative solutions. Investigation of the causes allow the problem solution to be determined from the treatment of the causes and not from its symptoms' point of view (BRAZIL, 2018).

In addition to investigating the causes, an analysis should be performed on the consequences, and their magnitudes and extents. This is a fundamental analysis to understand and demonstrate that the regulatory problem is sufficiently relevant. In order to justify a regulatory action, the problem must have sufficient repercussions on society and cannot be a mere isolated or circumstantial fact (BRAZIL, 2018).

In general, the problem analysis and definition involves consideration and knowledge about the following elements: i) problem context; ii) description of the problem and its consequences; iii) identification and analysis of the causes; iv) evidence gathering; v) consultation with affected stakeholders; vi) prioritization of regulatory action; and vii) description of the regulatory action objectives (ANVISA, 2019). The present study focused mainly on these elements: a) problem context; b) description of the problem and its consequences; $c$ ) identification and analysis of the causes; d) affected stakeholders definition; and e) description of the regulatory action objectives.

\section{Methods}

This is a descriptive study to demonstrate, with a qualitative approach, and through a didactic-pedagogical workshop, the potential use of problem analysis and definition as a "tool" to formulate policies and actions in coping with COVID-19. The pandemic spread of the virus and intense efforts to control it provide an opportunity to employ this RIA phase in an environment where involved managers and health professionals are daily overloaded and under pressure, hindering the development of critical thinking and the sense of collective engagement on how to make decisions in the face of the epidemic. The problem analysis and definition workshop can help decision makers to plan the regulatory challenges and actions, as well as anticipate future threats arising from COVID-19.

\section{Pre-workshop activity of problem analysis and definition}

A document was prepared by one of the authors to provide basic information for discussions on the problem analysis and definition workshop. This document contained epidemic/pandemic context data, addressing COVID-19 epidemiological aspects, forms of contagion, symptomatology, main risk groups and geographic distribution, as well as data and information about the social and economic impacts of the disease, including measures adopted 
to cope with it, especially those associated with social isolation and health care systems infrastructure.

The document was shared with the participants to provide basic information during the problem analysis and definition workshop, so they could develop critical thinking about the COVID19 epidemic in Brazil. Participants received the document in advance, so they could read and reflect on its contents.

\section{Main problem analysis and definition workshop}

Given the epidemic circumstances, the workshop took place virtually on May 7, 2020. The workshop lasted three hours with two intervals of five minutes each. The method used was inspired by Design Thinking tools.

Participants were encouraged to diverge and converge in the four planned stages of the workshop: i) main problem definition; ii) definition of main problem consequences; iii) definition of main problem causes; and iv) identification of potential affected stakeholders and definition of the degree to which they are affected by the main problem. At the beginning of the workshop, the following recommendations were made to the participants: a) have an open mind; b) avoid any type of judgement; and c) have a bias towards action. In this sense, all ideas presented by the participants, through the use of virtual self-adhesive notes, were considered.

During the first stage of the workshop, the participants were initially asked to reflect individually for five minutes and describe what the main problem related to COVID-19 is in their opinion. They were also recommended to avoid describing the problem as the absence of a solution. The use of self-adhesive notes was limited to two per participant, and each note should have contained a description of the main problem. Then, an affinity diagram was created to group similar ideas. Finally, a vote was held, with each participant entitled to two votes, in order to select the main problem.

In the second workshop stage, the participants were again requested to reflect individually for five minutes on what would be the main problem consequences, based on data and evidence presented in the document received during the pre-workshop activity. As it was a practical and illustrative exercise, the participants were recommended to list three to four consequences, describing each one on a virtual self-adhesive note. Subsequently, another affinity diagram was made to group similar consequences.

In the third workshop stage, participants were asked why the main problem exists, i.e., what would be its causes. They were then encouraged to use the information from the preworkshop document to describe the main problem causes. Participants were provided with 10 
minutes for individual consideration, and they were recommended to identify three to fourcauses each in one virtual self-adhesive note. Soon after, a new affinity diagram was built to group similar causes.

Finally, regarding the fourth and last workshop stage, the participants were requested to identify the potential stakeholders affected and to what degree of involvement they would be influenced by the main problem.

The participants were recommended to inspire themselves by the scientific evidences, the pre-workshop document, the problem description and its causes and consequences already listed, in order to describe the affected stakeholders.

For the definition of stakeholders' involvement degrees, a scale of five levels was established, the first corresponding to the least influenced stakeholders and the fifth to those most affected by the problem. First, the participants were provided with 10 minutes to think individually, with the recommendation to identify six affected stakeholders each, describing a stakeholder and his degree of involvement per self-adhesive note. One more time, an affinity diagram was elaborated to group similar affected stakeholders. By voting, the participants selected the final involvement degree corresponding to similar affected stakeholders, who, in some cases, previously had different degrees of involvement.

\section{Analysis workshop subjects and main problem definition}

Seven Anvisa federal employees and one trainee participated in the workshop. All of them currently working in Anvisa's area responsible for improving regulatory quality. One is an epidemiologist with experience in researching outbreaks and epidemics, two are health surveillance managers and other five participants are experienced in RIA methods and problem analysis and definition. Of the latter, two of them were responsible for the workshop moderation.

The definition of the quantity of eight workshop participants met the recommended by Fulton-Calkins et al (2010), who indicates the ideal quantity between seven and 15 people for problem solving and decision-making workshops. Moreover, the literature has suggested that cooperative groups perform better than independent individuals in a wide variety of problemsolving processes (KORIAT et al. 2016).

Although the workshop participants are not specialists in COVID-19, there was no harm in the didactic-pedagogical workshop outcome, as the objective was to demonstrate the potential of the problem analysis and definition as a "tool" for the formulation of policies and actions to cope with COVID-19. 


\section{Microsoft Teams and Mural Platforms}

The workshop took place using Microsoft Teams and Mural platforms. Microsoft Teams is an application that is part of the Office 365 suite. It is a teamwork hub where conversations, files, meetings, and applications are brought together in a single shared cloud workspace (Microsoft, 2020). During the workshop, Microsoft Teams was used for real-time video and audio interactions, as well as for written chat in a collaborative format.

Mural is a visual workplace that enables collaboration among remote team members, through whiteboards and virtual self-adhesive notes. It allows teams to collaborate visually to solve complex problems, as an easy-to-use software for creating diagrams used in Design Thinking and agile methodologies, in addition to stimulating participants' creativity (Mural, 2020). In this study's case, Mural played the role of virtual whiteboard and self-adhesive notes, using previously created templates based on Design Thinking tools already applied in face-to-face workshops at Anvisa.

\section{Information organization and results analysis and consolidation}

As seen in the previous subtopic, the affinity diagram was used to organize the participants' ideas in all stages. An affinity diagram is an approach designed to help organize disparate, loose, and unstructured ideas generated in brainstorming workshops, by consolidating them into clusters based on their natural relationships or priority patterns (NHS, 2011).

After the workshop, the results were analyzed and consolidated, in order to allow a general problem representation, containing the specific consequences, causes and objectives, as well as an affected stakeholders map. During the analysis, the possibility of minor reformulations in writings proposed by the participants was expected, preserving the central idea of the text. As an illustration, the RIA specific objectives were elaborated for some causes chosen by the authors.

\section{Results and discussions}

The results and discussions of this study are presented according to each workshop stage.

\section{The main problem}

After a process of discussion and convergence of ideas, the main problem to be addressed in the context of regulatory policy actions was defined as: "SARS-COV-2 coronavirus dissemination, as a little-known, untreated and highly contagious virus" (Table 1). For ELLIG et al. (2016), the first principle governing the regulatory review of the executive branch is that an agency must identify the problem it intends to solve, as well as assess its importance. This principle 
reflects the sensible notion that, before proposing any regulation, regulators have to understand the problem causes and consequences that the proposed regulation seeks to address.

Table 1. Main problem, consequences, causes, and specific objectives.

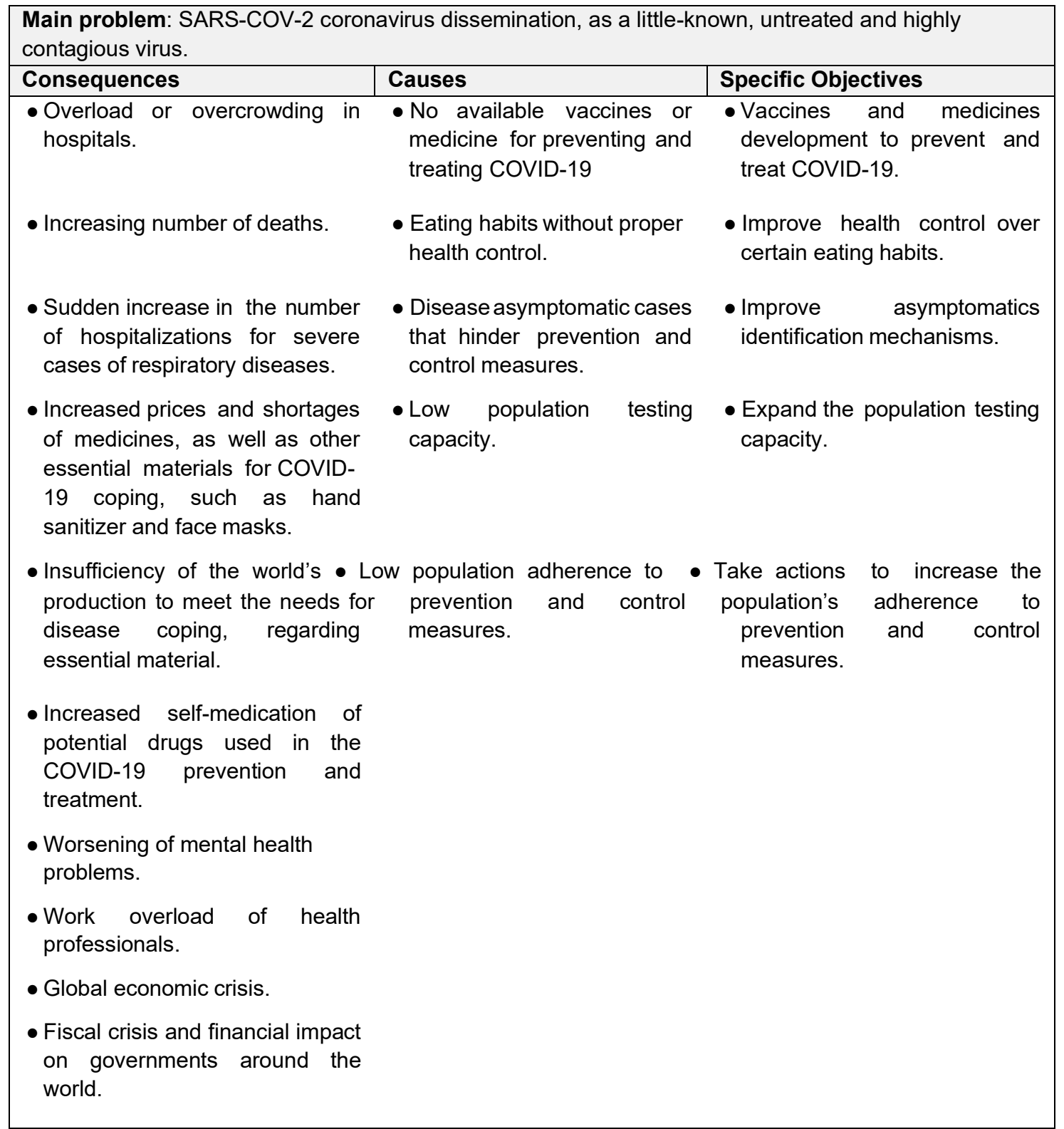

Source: Elaborated by the authors.

Besides fitting into the perspective of the conventional RIA approach, which emphasizes the presence of market failures as justification for government intervention (MENEGUIN et al. 2020), the main problem defined in the workshop presents another reason for government involvement, namely the promotion of meritorious goods' consumption. Merit goods are "commodities" considered goods for a person regardless of their own preferences, as they are 
partly defended with arguments that people do not always know what is best for them (FOLLAND et al. 2008). In this way, the public policies associated with coping with COVID-19 can be considered in the concept of meritorious goods.

The type of market failures that characterize the main problem includes the presence of incomplete information. Controlling the COVID-19 epidemic requires diagnostic testing, screening of symptomatic and asymptomatic patients, and information and communication about the disease nature and transmission. The information provided by diagnostic tests in asymptomatic patients, for instance, can create beneficial results to accelerate preventive and protective behaviors of the susceptible population (FOLLAND et al. 2008).

Table 2 provides evidence on the existence, magnitude and severity of the main problem, with systemic characteristics, at a national level. So far, the North (43.3/100,000 inhabitants), Northeast (24.9/100,000 inhabitants) and Southeast (22.7/100,000 inhabitants) regions had higher mortality rates per 100,000 inhabitants than the country's average $(20.9 / 100,000$ inhabitants). In absolute terms, the North region has the lowest number of hospital beds when compared to other Brazilian regions.

Table 2. Number of hospital beds, cases, deaths and mortality per 100,000 inhabitants, according to geographic regions of Brazil (updated: June 15, 2020, 6:30 p.m.).

\begin{tabular}{|c|c|c|c|c|c|}
\hline Main & peographic & $\begin{array}{c}\text { Number of } \\
\text { pospital } \\
\text { beds } \\
\text { regions/countr } \\
\mathbf{y}\end{array}$ & $\begin{array}{c}\text { Number } \\
\text { of } \\
\text { cases }\end{array}$ & $\begin{array}{c}\text { Number } \\
\text { of } \\
\text { deaths }\end{array}$ & $\begin{array}{c}\text { Mortality } \\
\text { per 100,000 } \\
\text { inhabitants }\end{array}$ \\
\hline \multirow{2}{*}{$\begin{array}{c}\text { SARS-COV-2 } \\
\text { coronavirus } \\
\text { dissemination } \\
\text { as a little- }\end{array}$} & North & 32,056 & 178,783 & 7,978 & 43.3 \\
\cline { 2 - 6 } known, & Midwest & 37,360 & 43,602 & 794 & 4.9 \\
\cline { 2 - 6 } $\begin{array}{c}\text { untreated and } \\
\text { highly } \\
\text { contagious } \\
\text { virus }\end{array}$ & Southeast & 179,257 & 311,716 & 20,062 & 22.7 \\
\cline { 2 - 6 } & South & 74,067 & 39,114 & 893 & 3.0 \\
\cline { 2 - 6 } & Brazil & $\mathbf{4 4 1 , 8 1 1}$ & $\mathbf{8 8 8 , 2 7 1}$ & $\mathbf{4 3 , 9 5 9}$ & $\mathbf{2 0 . 9}$ \\
\hline
\end{tabular}

Source: Prepared by the authors from Coronavirus/Brazil, 2020 and Ministry of Health, 2020.

The conceptual structure called Cynefin proposes that problems can be classified in four distinct domains. In the "simple" and "complicated" domains, problems assume orderly characteristics, with clear relationships between cause and effect, allowing the identification of a 
right, ideal and definitive answer. Regarding the "complex" and "chaotic" domains, there is no clear connection between cause and effect, and it is not possible to identify an ideal and definitive response. In the "chaotic" domain, there is high turbulence and decision-making takes place at an emergency level. In the "complex" domain, there is strong unpredictability and the need to experiment responses by monitoring their results (SNOWDEN et al, 2007).

Due to its contextual characteristics, it seems clear that the main problem identified in this study is between the "complex" and "chaotic" domains, which requires emergency measures and decision-making with the need of learning from the results monitoring.

\section{Main problem consequences}

The consequences show how the main problem affects people's lives. This helps to identify groups of affected stakeholders, choose specific objectives for RIA, and define messages for communication with society (VENEKLASEN et al. 2002). Depending on the stakeholder's perspective, consequences can be positive or negative. In this study, participants identified 10 consequences, which are characterized as negative from the point of view of citizens, companies and government.

The worsening of problems related to mental health was one of the consequences related to the main problem defined in the workshop (Table 1). The results of a study that analyzed the stress levels, anxiety and depression since the virus introduction and the levels of psychological symptoms, according to age, comorbidities and confinement in a sample of the Basque Country population (northern Spain), expose this consequence. According to this study, although symptom levels were low at the beginning of confinement, younger individuals with comorbidities reported more symptoms than the rest of the population. A higher level of symptoms was also detected since confinement, when the population was forbidden to leave their homes (OZAMIZETXEBARRIA et al. 2020).

Another consequence pointed out in the workshop was the global economic crisis due to the main problem. In order to highlight part of this consequence, ECLAC's report presents a catastrophic scenario for Latin America and the Caribbean. The COVID-19 effects will produce the largest recession that the region has suffered since 1914 and 1930, with a gross domestic product fall forecast of $-5.3 \%$ in 2020 (ECLAC, 2020). This recession is further accentuated in the forecasts made by the World Bank. According to the bank, multiple internal and external shocks resulting from the pandemic will cause a contraction in the regional economy of $7.2 \%$ in 2020 . According to projections, Brazil's economy is expected to shrink by $8 \%$ in 2020 due to total 
lockdowns, falling investments, supply chain disturbances and lower global primary product prices (WORLD BANK, 2020).

\section{The main problem causes}

The identification and selection of appropriate options to solve a problem should be guided by understanding its causes. Often, the problem causes in health systems are complex and uncertain, and it may be more appropriate to consider the underlying causes. The process of clarifying the cause or the underlying cause is unlikely to be simple or linear (COCHRANE, 2011). The problem causes are related to multifactorial aspects. The spread of coronavirus did not occur

for just one reason. The various problem causes have to be investigated, considered and prioritized, so as to allow the definition of clear objectives for regulatory and governmental action.

At the workshop, 20 causes were identified from the main problem determined by the participants, five of which are presented in Table 1 and were based on scientific evidence, as an illustration. It is certain that the problem causes are related to individuals and governments behaviors. These are behaviors that lead to the problem or contribute to its occurrence.

Behaviors related to eating habits and consumption of wild animals, without proper sanitary control, may have caused contamination by the virus (CASCELLA et al. 2020; SHEREEN et al. 2020), and the situation may have been aggravated by inaction of the Government of China, since the contagion began on December 16, 2019, until the adoption of severe containment measures on January 23, 2020 (LIN et al. 2020).

Coronavirus probably originated from bats, and then infected other mammalian hosts until it reached humans (CASCELLA et al. 2002). Based on the large number of infected people who were exposed to the wet animal market in Wuhan city (China), it is suggested that this is probably the zoonotic origin of COVID-19 (ROTHAN et al. 2020).

As the contamination progressed, after its early stages in China, some causes favored the high rate of contagion to occur. The existence of asymptomatic disease cases may have made it difficult to adopt prevention and control measures. A study conducted by Noshiura et al (2020) indicated that asymptomatic cases may represent up to $41.6 \%$ of all cases of the disease.

Besides the occurrence of asymptomatic cases, there are also symptomatic cases not confirmed by the low testing capacity in some countries and regions (RODRIGUEZ-MORALES et al. 2020). The ability to test everyone periodically through certification and monitoring is a viable way for society to resume life, without increasing contagion (PETO. 2020).

As severity of the pandemic progressed, government authorities started to adopt restrictive measures. However, some populations did not adhere to the restrictions. According to a study 
conducted by Dingel et al. (2020), only $37 \%$ of U.S. jobs can be fully performed at home. As the authors stated, this percentage is even smaller in lower-income countries. When the worker is unable to carry out his activities at home, it is natural that he does not obey the restriction imposed by his government. Financial needs, among other factors, lead people to leave home and not comply with restrictive measures.

From the identified and evidenced causes, it is possible to design specific objectives. Government action should be related to each of the specific objectives, in order to promote the coping with the causes and, consequently, the main problem. The specific objectives related to the five causes addressed in this study can be found in Table 1.

\section{Potential stakeholders affected by the main problem}

Thirty stakeholders affected by the main problem were identified during the workshop, ten of which were included in the highest degree of involvement according to the five-level scale previously established (Table 3). In this highest degree of involvement is, for example, the population of risk groups, such as the elderly and people with comorbidities.

As stated in a study conducted in China, approximately $80 \%$ of the patients have mild symptoms and the overall lethality rate is about $2.3 \%$, reaching $8.0 \%$ in patients aged between 70 and 79 years old and $14.8 \%$ in those aged > 80 years old (WU et al. 2020).

Data from Italy indicate the population groups with higher risk of having a severe stage of COVID-19 and death. These groups are the elderly over 70 years of age and people with comorbidities such as hypertension, diabetes, cardiovascular diseases, chronic respiratory diseases and cancer. Men in these groups seem to be at higher risk than women. Chronic obstructive pulmonary disease, cardiovascular diseases and hypertension were identified as strong predictors of admission to the Intensive Care Unit. The authors also highlight the importance of identifying smokers as a potentially vulnerable COVID-19 group (ECDC, 2020).

In order to obtain more effective participation and support, it is important to understand not only who the affected stakeholders are, but also the nature of their interest and influence on the main problem. By understanding this point, it is possible to involve these stakeholders and even address their concerns by demonstrating how proposing solutions to the problem would benefit them. Depending on the objectives, RIA may focus on those stakeholders with greater interest and influence and/or those who are most affected by the main problem. 
Table 3. Affected stakeholders and their degree of involvement with the main problem.

\begin{tabular}{|c|c|c|}
\hline Main problem & Affected stakeholders $(n=30)$ & $\begin{array}{l}\text { Degree of } \\
\text { involvement }\end{array}$ \\
\hline \multirow{5}{*}{$\begin{array}{c}\text { SARS-COV-2 } \\
\text { coronavirus } \\
\text { dissemination, as a little- } \\
\text { known, untreated and } \\
\text { highly contagious virus }\end{array}$} & $\begin{array}{l}\text { Total = } 10 \\
\text { - Risk group populations, such as the elderly and } \\
\text { people with comorbidities. } \\
\text { - Health professionals working on the front line of } \\
\text { coping with the disease. } \\
\text { - Hospitals and other health units. } \\
\text { - Ministry of Health. } \\
\text { - Low income population. } \\
\text { - Self-employed workers. } \\
\text { - Manufacturers of sanitizing products. } \\
\text { - Bars, restaurants and clubs. } \\
\text { - Professionals who cannot stay at home. } \\
\text { - Governments (sectors of economics and } \\
\text { planning). }\end{array}$ & +++++ (greater) \\
\hline & $\begin{array}{l}\text { Total = } 13 \\
\text { - Biochemical testing laboratories. } \\
\text { - Local businesses. } \\
\text { - National System of Health Surveillance. } \\
\text { - Middle- and high-income populations. } \\
\text { - Population outside risk groups. } \\
\text { - Researchers and research centers in general. } \\
\text { - Anvisa. } \\
\text { - Ports, airports and borders. } \\
\text { - Health departments. } \\
\text { - Workers from essential sectors, except health } \\
\text { and economy. } \\
\text { - Immigrants. } \\
\text { - Big companies. } \\
\text { - Health equipment manufacturers (e.g. artificial } \\
\text { respirators). }\end{array}$ & ++++ \\
\hline & $\begin{array}{l}\text { Total = } 7 \\
\text { - Electoral process (politicians). } \\
\text { - Startups (innovation companies). } \\
\text { - Professionals working in home offices. } \\
\text { - Children and young people. } \\
\text { - Unions and employee associations. } \\
\text { - Medicine distributors. } \\
\text { - Packaging manufacturers. }\end{array}$ & +++ \\
\hline & No affected stakeholder was identified & ++ \\
\hline & No affected stakeholder was identified & $+($ minor $)$ \\
\hline
\end{tabular}

Source: Elaborated by the authors.

The results of this study need to be considered in light of their limitations when demonstrating, through a didactic-pedagogical practical exercise, the importance of RIA, 
specifically in the problem analysis and definition phase. The problem understanding depends on the subjective view of those who are involved with the situation (ANVISA, 2019).

Moreover, not all consequences, causes and affected stakeholders defined in the workshop were fully explored. In a real-world study of RIA, all elements from its phases must be substantiated through scientific and also colloquial evidences (SHARMA et al. 2015). Other important consequences, causes and affected stakeholders may not have been identified in the didactic-pedagogical workshop. Furthermore, it is expected that these elements may undergo changes due to the epidemic/pandemic stages and the levels of government management in coping with COVID-19.

\section{Final considerations}

This study is a timely contribution to the COVID-19 response in Brazil, as well as to other future public health emergencies. It was possible to identify that performing problem analysis and definition workshops, within the scope of Regulatory Impact Assessment (RIA) and in a context of epidemic/pandemic, can promote effective solutions for the several stages of a public health emergency. Problem analysis and definition improves the process of generating solutions, that is, people's ability to produce high-quality alternatives to specific problems (NEZU et al. 1981).

The results of this study presented theoretical and practical contributions. From the theoretical point of view, the study contributed to the knowledge field that relates RIA to decisionmaking in moments of pandemics. The study presented logical concepts and connections with high research potential and application for policies and action formulation to cope with COVID-19, contributing to a research gap identified in the work of Mota et al (2020).

From a practical point of view, the results of this research indicated that public institutions could use the rationale offered by RIA to develop policies and actions to cope with COVID-19 and other public health emergencies. The collaborative workshop, using Design Thinking tools, proved to be useful to promote reflections and information gathering, as well as solutions and actions to deal with the pandemic. RIA offers a logical rationale that can be used in an environment where the professionals involved are directly under pressure, contributing to more planned and integrated public policies and government actions.

In addition, researchers and decision makers can continue this study to fully achieve the objectives of the response to COVID-19, from the development of subsequent stages of RIA, i.e., identification and comparison of regulatory options, monitoring and evaluation of the proposed solutions after implementation. 


\section{References}

ANVISA. Brazilian Health Regulatory Agency. Ordinance No. 1,741 of December 12, 2018. It provides for guidelines and procedures for improving regulatory quality at the Brazilian Health Regulatory Agency (Anvisa). Official Gazette, Brasilia, DF, 14 Dec. 2018a. Section 1, p.51.

ANVISA. Brazilian Health Regulatory Agency. Order of Service No. 56 of December 18, 2018. 2018b.

ANVISA. Brazilian Health Regulatory Agency. Regulatory Impact Assessment Guide. Brasilia: Anvisa. 2019.

ANVISA. Brazilian Health Regulatory Agency. Institutional website. Available at: <http://www.anvisa.gov.br>, accessed on: June 4, 2020.

AQUILA, Giancarlo; PAMPLONA, Edson de Oliveira; FERREIRA FILHO, José Alberto; SILVA, Antonio Sergio da; MATAVELI, José Victor de Azevedo et al. Quantitative regulatory impact analysis: Experience of regulatory agencies in Brazil. Utilities Policy, v.59, August 100931, 2019.

BALLANTINE, Bruce; DEVONALD, Bethan (2009). Modern regulatory impact analysis: The experience of the European Union. Regulatory Toxicology and Pharmacology, v. 44, n. 1, pp. 5768, 2006.

BRAZIL. The Staff of the Presidency of the Republic. General Guidelines and Guidance for Preparation of Regulatory Impact Assessment - RIA. Brasilia: Presidency of the Republic, 2018.

BRAZIL. Ministry of Health. Ordinance No. 454 of March 20, 2020. It declares throghout the national territorry the state of coronavirus (COVID-19) transmission. Brasilia/DF: Ministry of Health, 2020.

CARVALHO, Bruno Eustáquio de; COSTA, Ana Sara; MARQUES, Rui Cunha; NETTO, Oscar Cordeiro. The presence of governance: A system assessment based on innovative core regulatory principles for Brazilian regulators. Expert Systems, v. 36, n. 4, pp.1-21, 2019.

CASCELLA, Marco; RAJNIK, Michael; CUOMO, Arturo; DULEBOHN, Scott; DI NAPOLI, Rafaella. Features, Evaluation and Treatment Coronavirus (COVID-19), April 6, 2020. Available at: <https://https://www.ncbi.nlm.nih.gov/books/NBK554776/>. Accessed on: June 5, 2020.

CASTRO, Camila Moreira de. Some aspects of implementing Regulatory Impact Analysis in Brazil. Public Administration Magazine, v. 48, n. 2, pp. 323-342, 2014. 
CAVALCANTE, Pedro.; MENDONÇA, Letícia; BRANDALISE, Isabella. Public policy and design thinking: interactions to face contemporary challenges. In: CAVALCANTE, Pedro. Innovation and Public Policy: overcoming the myth of the idea. Chapter 1, Brasilia: IPEA, pp. 29-52, 2019.

ECLAC. Economic Comission for Latin America and the Caribbean. Dimension the effects of COVID-19 to think about reactivation. Special Report COVID-19 No. 2. 2020.

COCHRANE. What is the cause of the problem? November 2011. Available at: https://epoc.cochrane.org/sites/epoc.cochrane.org/files/public/uploads/SURE-Guidesv2.1/Collectedfiles/source/03_clarifying_problem/cause_problem.html. Accessed on: May 31, 2020.

CORONAVIRUS/BRAZIL. Covid-19 Coronavirus Panel 2020. Available at: < https://covid.saude.gov.br/ >. Accessed on: June 16, 2020.

COVID-19, a pandemic or not? The Lancet, v. 20, April, p.383, 2020.

COWPER, Andy. COVID-19: are we getting the communications right? BMJ, 368, m919, 2020.

DASKAL, Shira; AYALON, Ofira; SHECHTER, Mordechai. Closing the Loop: the Challenges of Regulation in Municipal Solid Waste Management. Detritus, In Press, January, pp.1-8, 2019.

DELIVORIAS, Angelos; SCHOLZ, Nicole Scholz. Economic impact of epidemics and pandemics. European Parliamentary Research Service. February 2020.

DINGEL, Jonathan; NEIMAN, Brent. How many jobs can be done at home? National Bureau of Economic Research, March, pp.16-24, 2020.

DUDLEY, Susan; BELZER, Richard; BLOMQUIST, Glenn; BRENNAN, Timothy; CARRIGAN, Christopher et al. Consumer's Guide to Regulatory Impact Analysis: Ten Tips for Being an Informed Policymaker. Journal of Benefit-Cost Analysis, V. 8, No. 2, pp. 187-204, 2017.

KORIAT, Asher; ADIV, Shiri. The self-consistency theory of subjective confidence. In: DUNLOSKY, John; TAUBER, Sarah. The Oxford Handbook of Metamemory. Oxford University Press, Chapter 8, pp.127-148, 2016.

ECDC. European Centre for Disease Prevention and Control. Coronavirus disease 2019 (COVID-19) pandemic: increased transmission in the EU/EEA and the UK - seventh update. March 25, 2020. Available at: < https://www.ecdc.europa.eu/sites/default/files/documents/RRAseventh-update-Outbreak-of-coronavirus-disease-COVID-19.pdf>. Accessed on: June 4, 2020. 
ELLIG, Jerry; BROUGHEL, James; BELL, Spencer. Regulating Real Problems: The First Principle of Regulatory Impact Analysis. Mercatus Center. George Mason University, March 9, 2016. Available at: <https://www.mercatus.org/publications/regulation/regulating-real-problems-firstprinciple-regulatory-impact-analysis>. Accessed on: May 30, 2020.

FOLLAND, Sherman; GOODMAN, Allen C.; STANO, Miron. The health economy. $5^{\text {th }}$ Edition. Porto Alegre: Bookman, 2008.

FRANCESCO, Fabrizio de. Diffusion of Regulatory Impact Analysis Among OECD and EU Member States. Comparative Political Studies, V. 45, No. 10, pp. 1277-1305, 2012.

FRITSCH, Oliver; RADAELLI, Claudio M, SCHREFLER, Lorna; Renda, Andrea. Comparing the content of regulatory impact assessments in the UK and the EU. Public Money and Management, V. 33, No. 6, pp. 445-452, 2013.

FULTON CALKINS, Patsy; RANKIN, Dianne; SHUMACK, Kellie. The administrative professional: Technology \& procedures. Cengage Learning, 2010

HASSAN, Kamal H. Regulatory Impact Analysis in Legal Research: Way Forward for Malaysian Legislation. Mediterranean Journal of Social Sciences, V.6, No. 3, pp. 520-524, 2015.

HEALTH MINISTRY. CNES - Physical Resources - Hospital - Inpatient Beds - Brazil, April 2020. Available at: <http://tabnet.datasus.gov.br/cgi/tabcgi.exe?cnes/cnv/leiintbr.def>. Accessed on: June 15, 2020

HUGÉ, Jean; WAAS, Tom. Converging impact assessment discourses for sustainable development: The case of Flanders, Belgium. Environment, Development and Sustainability, V. 13, No. 3, pp. 607-626, 2011.

IBRAC. Institutionalization and practice of Regulatory Impact Analysis in Brazil. Sao Paulo: IBRAC, 2019, 333p.

JACOBS, Scott. Regulatory impact assessment and the economic transition to markets. Public Money and Management, V. 24, No. 5, pp.283-290, 2004.

JOHNS HOPKINS UNIVERSITY \& MEDICINE. COVID-19 Dashboard by the Center for Systems Science and Engineering (CSSE) at Johns Hopkins University. 2020. Johns Hopkins Coronavirus Resour. Cent. Available at: <https://coronavirus.jhu.edu/map.html>. Accessed on: June 6, 2020.

KIRKPATRICK, Colin; PARKER, David; ZHANG, Yin-Fang. Regulatory impact assessment in developing and transition economies: A survey of current practice. Public Money and Management, V. 24, No. 5, pp. 291-296, 2004. 
KRUMKAMP, Ralf; AHMAD, Amena; KASSEN, Annette; HJARNOE, Lulu; SYED, Armed M. et al. Evaluation of national pandemic management policies-A hazard analysis of critical control points approach. Health Policy, V. 92, No. 1, pp. 21-26, 2009.

LIN, Qianying; ZHAO, Shi; GAO, Daozhou; LOU, Yijun; YANG, Shu et al. A conceptual modelfor the outbreak of Coronavirus disease 2019 (COVID-19) in Wuhan, China with individual reaction and governmental action. International journal of infectious diseases, V. 93, No. 1, pp. 211-216, 2020.

LIPSITCH, Marc.; SWERDLOW, David L.; FINELLI, Lyn. Defining the Epidemiology of Covid-19 - Studies Needed. New England Journal Medicine, V. 382, No. 13, pp. 1194-1196, 2020.

McLAUGHLIN, Jacqueline E.; WOLCOTT, Michael D.; HUBBARD, Devin; UMSTEAD, Kelly; RIDER, Traci R. A qualitative review of the design thinking framework in health professions education. BMC Medical Education, V. 19, N. 98, pp.1-8, 2019.

MENEGUIN, Fernando B.; SAAB, Flavio. Regulatory Impact Assessment: perspectives based on the Economic Freedom Law. Brasilia: Center for Studies and Research/CONLEG/Senado, Feb. 2020 (Text for Discussion No. 271). Available at: <www.senado.leg.br/estudos>. Accessed on: February 20, 2020.

MICROSOFT. Microsoft Teams nothing can stop a team. 2020. Available at: <https://www.microsoft.com/pt-br/microsoft-365/microsoft-teams/group-chat-software>. Accessed on: June 4, 2020.

MOTA, Daniel Marques; FERREIRA, Paulo José Gonçalves; LEAL, Lisiane Freitas (2020). Scientific production on COVID-19 in Brazil: a scope review. Health Surveillance in Debate: Society, Science \& Technology, V.8, 2020. In the press.

MURAL. Put imagination to work. 2020. Available at: <https://www.mural.co/>. Accessed on: June 4, 2020.

NEZU, Arthur; D'ZURILLA, Thomas J. Effects of Problem Definition and Formulation on Decision Making in the Social Problem-Solving Process. Behavior Therapy, V. 12, pp. 100-106, 1981.

NHS Improvement. Guidance - How to create an affinity diagram. October 2011. Available at: <https://www.england.nhs.uk/improvement-hub/wp-content/uploads/sites/44/2017/11/Creatingan-Affinity-Diagram.pdf>. Accessed on: June 2, 2020. 
NISHIURA, Hiroshi; KOBAYASHI, Tetsuro; MIYAMA, Takeshi; SUZUKI, Ayako; JUNG, Sungmok et al. Estimation of the asymptomatic ratio of novel coronavirus infections (COVID19). International Journal of Infectious Diseases, V. 94, pp. 154-155, 2020.

PAHO/WHO Brazil - Fact sheet - COVID-19 (disease caused by the new coronavirus) | PAHO/WHO. Updated April 30, 2020. Available at: https://www.paho.org/bra/index.php?option=com_content\&view=article\&id=6101:covid19\&ltemid =875. Accessed on: May 1, 2020.

OZAMIZ-ETXEBARRIA, Naiara; DOSIL-SANTAMARIA, Maria; PICAZA-GORROCHATEGUI, Maitane; IDOIAGA-MONDRAGON, Nahia. Stress, anxiety and depression levels in the first phase of the COVID-19 outbreak in a sample collected in northern Spain, Cad. Public Health. 2020, V. 36, No. 4, e00054020, 2020.

PETO, Julian. Covid-19 mass testing facilities could end the epidemic rapidly. Bmj, 2020, V.368, No.1, pp.1, 2020.

RADAELLI, Claudio Maria. Getting to grips with quality in the diffusion of regulatory impact assessment in Europe. Public Money and Management, V. 24, No. 5, pp. 271-276, 2004.

RADAELLI, Claudio Maria. Rationality, Power, Management and Symbols: Four Images of Regulatory Impact Assessment. Scandinavian Political Studies, V. 33, No. 2, pp. 164-188, 2009. RODRIGUEZ-MORALES, Alfonso J.; GALLEGO, Viviana; ESCALERA-ANTEZANA, Juan Pablo; MENDEZ, Claudio A.; ZAMBRANO, Lysien I. et al. COVID-19 in Latin America: The implications of the first confirmed case in Brazil. Trav Med Infect Dis, V. 29, No. 2, pp.1-3, 2020.

ROTHAN, Hussin; BYRAREDDY, Siddappa. The epidemiology and pathogenesis of coronavirus disease (COVID-19) outbreak. Journal of autoimmunity, V. 109, No. 1, pp.1-4, 2020.

SHARMA, Tarang; CHOUDHURY, Moni; KAUR, Bindweep; NAIDOO, Bhash; GARNER, Sarah et al. Evidence informed decision-making: the use of "colloquial evidence" at nice. Int $J$ Technol Assess Health Care, V.31, No.3, pp.138-46, 2015.

SHEREEN, Muhammad Adnan; KHAN, Suliman; KAZMIN, Abeer; BASHIR, Nadia; SIDDIQUE, Rabeea. COVID-19 infection: Origin, transmission, and characteristics of human coronaviruses. Journal of Advanced Research, V. 24, No. 1, pp.91-98, 2020.

SNOWDEN, David. J.; Boone, Mary E. A leader's framework for decision-making. Harvard business review, V.85, No.11, 68, 2007. 
VENEKLASEN, Lisa; MILLER, Valerie. Causes, consequences, and solutions. PLA Notes, 43: 1819, 2002. Available at: <https://pubs.iied.org/pdfs/G01977.pdf>. Accessed on: June 3, 2020.

WORLD BANK. World Economic Perspectives: Latin America and the Caribbean. June 2020. Available at: < https://www.worldbank.org/pt/publication/global-economic-prospects> Accessed on: June 15, 2020.

WU, Zunyon; McGOOGAN, Jennifer M. Characteristics of and important lessons from the coronavirus disease 2019 (COVID-19) outbreak in China: summary of a report of 72,314 cases from the Chinese Center for Disease Control and Prevention. JAMA, Feb 24, 2020.

\section{Daniel Marques Mota}

http://orcid.org/0000-0003-4156-0138

$\mathrm{PhD}$ in Epidemiology at the Federal University of Rio Grande do Sul (UFRGS).

Civil servant at the Brazilian Health Regulatory Agency (Anvisa).

E-mail: dmarques2003@yahoo.com.br

\section{Flavio Saab}

https://orcid.org/0000-0002-3913-4175

Collaborating professor at the Department of Public Policy Management at the University of Brasília (GPP/UnB). Civil servant at the Brazilian Health Regulatory Agency (Anvisa).

E-mail: flaviosaab@gmail.com

Raisa Zandonade Vazzoler

https://orcid.org/0000-0001-7744-9410

Graduated in Food Engineering at the Federal University of Viçosa (UFV).

Civil servant at the Brazilian Health Regulatory Agency (Anvisa).

E-mail: vazzolerraisa@gmail.com

\section{Karina Schunig}

http://orcid.org/0000-0002-4342-3527

MBA in IT Service Management by the Brazilian Institute of Advanced Technology (IBTA).

Civil servant at the Brazilian Health Regulatory Agency (Anvisa).

E-mail: karinaschunig@hotmail.com

\section{Edson Antônio Donagema}

https://orcid.org/0000-0002-5149-4616

Specialist in Collective Health at the State University of Campinas (Unicamp).

Civil servant at the Brazilian Health Regulatory Agency (Anvisa).

E-mail: edsondonagema@yahoo.com.br

\section{Gabrielle Cunha Barbosa Cavalcanti e Cysne Troncoso}


http://orcid.org/0000-0002-0881-5162

Specialist in Health Economics at the University of São Paulo (USP) and in Health Surveillance at the Oswaldo Cruz Foundation (Fiocruz). Civil servant at the Brazilian Health Regulatory Agency (Anvisa).

E-mail: gabrielle.troncoso@yahoo.com.br 